\title{
Determining the most appropriate form of Urban Building Energy Simulation Model for the city of Ahmedabad
}

\author{
Pamela Jane Fennell ${ }^{1}$, Paul Anthony Ruyssevelt ${ }^{1}$, Rajan Rawal ${ }^{2}$, Veeren Poola ${ }^{2}$ \\ ${ }^{1}$ Energy Institute, University College London, London, UK \\ ${ }^{2}$ CEPT University, Ahmedabad, India
}

\begin{abstract}
A review of existing large-scale building energy models was undertaken, highlighting their prevalence at geographically higher latitudes. The ability of these models to adequately represent cities in the global south is questionable and existing classifications are inadequate to describe the diversity of models that have been developed. As a response, a novel model classification scheme was developed to explore how the various models capture the underlying physical context, and to assess their appropriateness for application to the city of Ahmedabad in western India.

The model classification scheme was used to develop a characteristic map for the new model of Ahmedabad and define priorities for the model's development.
\end{abstract}

\section{Introduction}

Within 30 years, India's urban population will overtake its rural population, with 300 million additional people living in urban settlements. These new urban dwellers will overwhelmingly inhabit the largest cities (United Nations, Department of Economic and Social Affairs, Population Division, 2018). This rapid urbanization has profound implications for India's energy demands: in $2013,65 \%$ of building energy consumption was in the form of biomass; by 2030, 60\% will be supplied from oil and gas (International Energy Agency, 2015). Shnapp and Lausten (2013) warned that "current trends show that, without a transformational change, energy consumption of buildings will increase to levels that are unsustainable and threatening to India's energy security. However, improving the energy performance of existing and new buildings can have a major role in managing energy and $\mathrm{CO}_{2}$ emissions."

A wide range of tools have been developed to map this demand, ranging from statistical models of city-level consumption to models considering the consumption at the level of the individual building. The aim of this study is to review and categorise the range of models available, to identify the most suitable form for the Indian context. In the first instance, this model will be developed for the city of Ahmedabad, the largest city in Gujarat and a major industrial and financial hub in western India.

The key requirement of the model to be developed is that it should support progress on India's deep decarbonisation pathway by mapping current and future energy demand reduction opportunities in the built environment. It should allow diagnosis of urban energy problems, testing of solutions, verification of progress, and improvements in policy decisions.

This process was undertaken as follows:

The large-scale building energy model literature was surveyed to identify existing examples and the locations to which they have been applied.

The differences between the Indian context and the northern hemisphere (where most of the models have been applied) are explored.

A detailed review of a selection of the literature is undertaken and models classified according to their characteristics.

The significance of gaps between characteristics of existing models and the demands of the model context is considered and a development plan set out for the new model.

\section{The range of existing UBEMs}

Urban Building Energy Models have traditionally been categorised as either top-down or bottom-up models, according to whether the starting point is stock level energy consumption which must be broken down into its constituent parts, or energy consumption of individual units, which must be aggregated to determine stock level demand (e.g. Swan \& Ugursal, 2009). Bottom-up models can further be broken down into statistical models which use historical data and assess the relationships between building information and energy use data; and building physics-based models (Lim \& Zhai, 2017).

Building physics-based models have been selected as the most appropriate form of building-stock energy model for this project due to the need to be able to model retrofit solutions which may impact on more than one building system (Chen, Hong, \& Piette, 2017).

For this study a model was considered to consist of 3 layers, as proposed by Chen et al. (2017):

- a data layer

- an algorithm/engine software layer in which data is processed and outputs calculated

- an application layer containing the model outputs.

A title, keyword and abstract search was undertaken using the scopus database, the search query used was:

"Building Stock" OR "Urban" OR "City" OR "Regional" located within three words of "Energy", located within three words of "Model" AND "Building". 
The search period was limited to literature dating from 2010 and later. Applications of the model were required to include at least 100 buildings for inclusion. A total of 177 records were identified for which abstracts were manually screened leading to the retention of 71 records. The location of each case was extracted from the abstract or, in a small number of cases where not detailed in the abstract, from a full text review.
Figure 1 shows the results of this survey: coverage is much greater in the USA and Europe than the rest of the world, although China is reasonably well represented. Coverage is notably absent in low- and middle-income developing countries, in South America, Africa and Southern and South Eastern Asia.

The potential implication of this pattern of application are considered next.

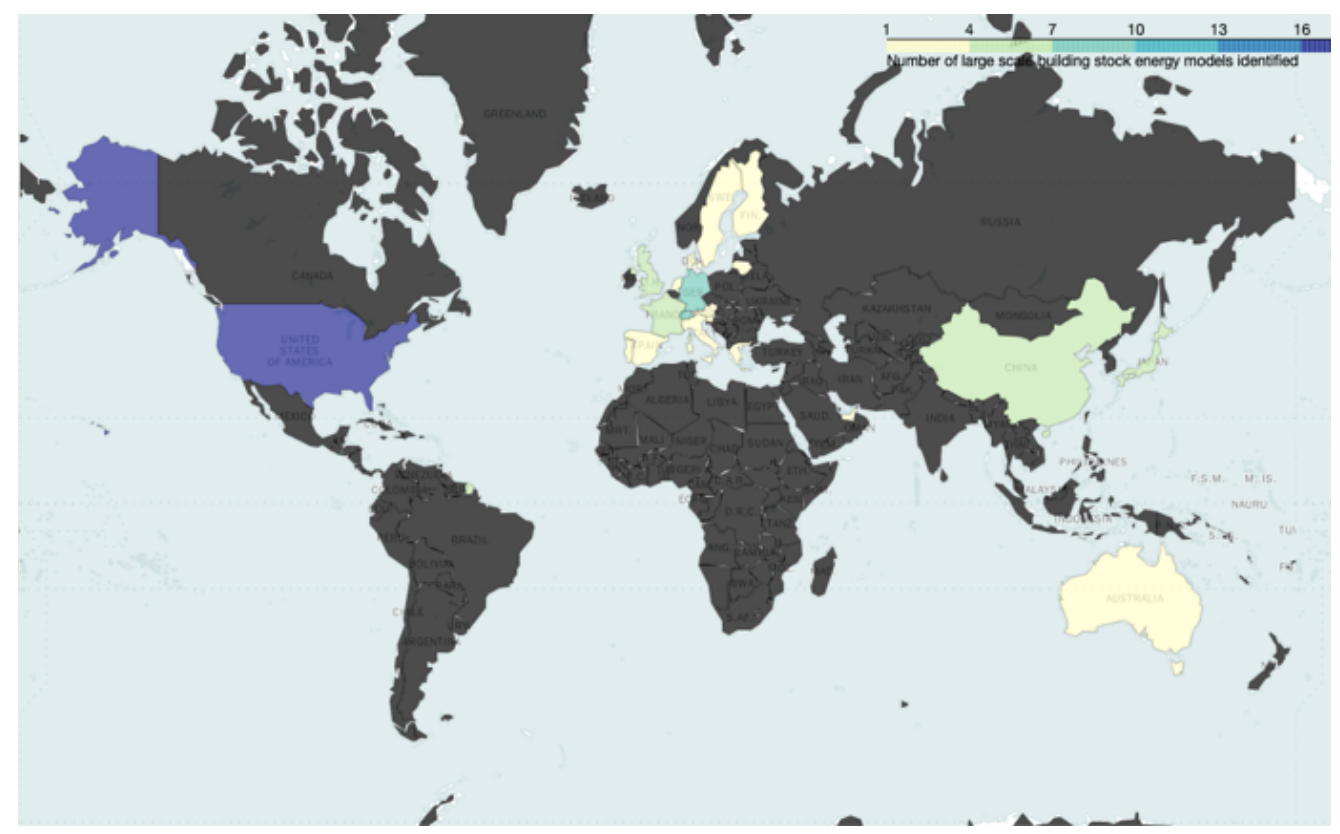

Figure 1: Geographic distribution of urban and city scale models (created using folium 0.10.0)

\section{The importance of context}

While the underpinning framework of building physics makes it tempting to view a UBEM as a neutral tool to be applied to answer a given question, the process of modelling is inherently value-laden. Roman Frigg (2010) draws a clear distinction between two parts of the process of model making - the presentation of a hypothetical system as the object of study (the model system) and the representational relationship with the part of the world we are interested in (the target system). The process of representation necessarily involves simplification and judgements must be made about which details should be included. This process raises the question: "What relation does the model have to bear to the target and what is the role of conscious users when a model system is used to represent something?" (Frigg 2010, 252).

The challenges of modelling at city-scale are largely driven by the scale of the target system as noted by Frayssinet et al. (2018) and thus the level of judgement employed in developing a model system which fits the limits of available computational power can be considerable.

- Models based on developed cities may not be able to represent the stock dynamics of developing cities,
Manu et al. (2011) estimated that 70\% of India's 2030 building stock had not yet been built.

- The building systems and equipment needed in climate zones with a winter heating season are different to those with a cooling summer season which may result in prioritisation of different aspects of UBEM. Davis and Gertler (2017) estimate that India has a potential cooling demand twelve times higher than that of the United States for example.

- Higher surface temperatures mean increased importance of longwave radiative heat transfer between surfaces (Evins, Dorer, \& Carmeliet, 2014).

- Availability of data on buildings, their function and their energy consumption underpin bottom up models; however, building energy data availability and robustness differ dramatically between countries and regions of the world (Shnapp \& Laustsen, 2013). In addition, practices of energy consumption are often very different in countries where energy demand is financially constrained (Roy, 2000).

Importantly, if these implications are overlooked, there is a real potential for harm: Sunikka-Blank et al. (2019, p. 53) detail the negative impacts of poorly-planned slum rehabilitation in Mumbai where "changed practices, poor design of [replacement housing] and lack of outdoor space have radically increased electricity use and living costs in all the surveyed households." 


\section{Understanding the characteristics of existing models}

Having established that the majority of existing largescale building energy models have been developed for contexts which are very different to the one this study is focused on, it was necessary to explore the characteristics of each model in more detail to understand how well they might meet the needs of a rapidly expanding city in the global south (dados \& connell, 2012), such as Ahmedabad. The high-level classification of existing frameworks (e.g. Lim \& Zhai, 2017; Swan \& Ugursal, 2009) does not provide sufficient detail to be able to assess the appropriateness of different model characteristics for application in a new setting.

A new concept for a model classification scheme is developed here, drawing on the ASHRAE characteristics; this scheme is visualised as overlapping layers (see Figure 2). At the core are building users, and how they and their interactions with the buildings they inhabit are captured. A building layer describes the envelope and systems which enclose and interact with the user. The environmental layer addresses the context in which each building is situated. Wrapping around all of these is a methodological layer capturing key choices in how models are structured and the outputs they produce. The progression from the micro to meso (and possibly beyond to the macro or national scale) enables a much fuller description of the modelling approach. While all of the models considered in this study address the meso-scale, the need to balance competing priorities of computational burden and complexity mean that the level of detail in which micro-scale parameters are considered varies significantly. This balance is highly dependent on purpose of the model and the appropriate balance for the model of Ahmedabad is discussed further later in this paper.

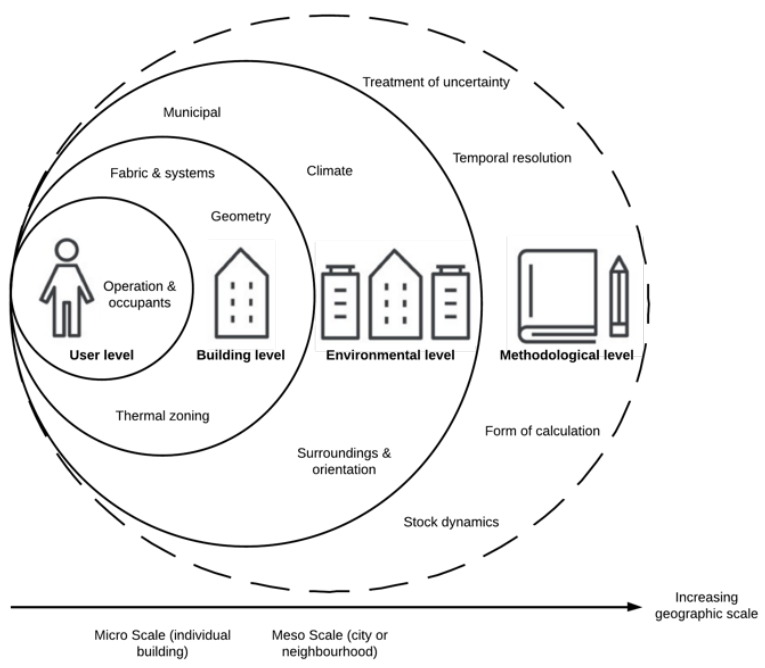

Figure 2: Model classification framework

In total 11 different model characteristics were identified in these four layers, which define the differences between the reviewed models. For each characteristic a series of descriptors were established to describe the different approaches. Table 1 sets out the classification scheme and the descriptors together with examples identified in the literature.

Table 1: Classification scheme

\begin{tabular}{|c|c|c|c|c|}
\hline Layer & Characteristic & Descriptor & Count & Examples \\
\hline \multirow{4}{*}{$\begin{array}{l}\dot{\bar{d}} \\
\stackrel{0}{D}\end{array}$} & \multirow{4}{*}{$\begin{array}{l}\text { Occupant and } \\
\text { Occupancy } \\
\text { Related }\end{array}$} & Single profile & 9 & $\begin{array}{l}\text { (Caputo, Costa, \& Ferrari, 2013; Dall'O', Galante, } \\
\text { \& Torri, 2012; Filogamo, Peri, Rizzo, \& Giaccone, } \\
\text { 2014) }\end{array}$ \\
\hline & & Multiple profiles & 17 & $\begin{array}{l}\text { (Clarke, Ghauri, Johnstone, Kim, \& Tuohy, 2008; } \\
\text { Dogan \& Reinhart, 2017; Heiple \& Sailor, 2008) }\end{array}$ \\
\hline & & $\begin{array}{l}\text { Stochastic selection } \\
\text { from predefined sets of profiles }\end{array}$ & 6 & $\begin{array}{l}\text { (Cerezo Davila, 2017; Cerezo Davila, Jones, Al- } \\
\text { Mumin, Hajiah, \& Reinhart, 2017; Evans, Liddiard, } \\
\text { \& Steadman, 2017) }\end{array}$ \\
\hline & & $\begin{array}{l}\text { Stochastic generation } \\
\text { e.g. agent-based modelling }\end{array}$ & 1 & $\begin{array}{l}\text { (Nägeli, Camarasa, Jakob, Catenazzi, \& } \\
\text { Ostermeyer, 2018) }\end{array}$ \\
\hline \multirow{7}{*}{$\stackrel{\substack{g \\
:}}{:}$} & \multirow{4}{*}{$\begin{array}{l}\text { Level of } \\
\text { Geometric } \\
\text { Detail }\end{array}$} & $\begin{array}{l}\text { Extruded } \\
\text { Cuboid based on floor area }\end{array}$ & 17 & $\begin{array}{l}\text { (Filogamo et al., 2014; Heiple \& Sailor, 2008; Mata, } \\
\text { Kalagasidis, \& Johnsson, 2013) }\end{array}$ \\
\hline & & $\begin{array}{l}\text { LOD1 } \\
\text { Extruded floor plan }\end{array}$ & 13 & $\begin{array}{l}\text { (Chen et al., 2017; Evans et al., 2017; Mhalas, } \\
\text { Kassem, Crosbie, \& Dawood, 2013) }\end{array}$ \\
\hline & & $\begin{array}{l}\text { LOD2 } \\
\text { as LOD1 with roof form included }\end{array}$ & 2 & (Caputo et al., 2013; Kaden \& Kolbe, 2013) \\
\hline & & $\begin{array}{l}\text { LOD3 } \\
\text { as LOD2 with exterior windows }\end{array}$ & 0 & \\
\hline & \multirow{3}{*}{$\begin{array}{l}\text { Thermal } \\
\text { Zoning }\end{array}$} & $\begin{array}{l}\text { Simple } \\
\text { single zone per building or floor }\end{array}$ & 26 & $\begin{array}{l}\text { (Booth, Choudhary, \& Spiegelhalter, 2012; Fonseca } \\
\text { \& Schlueter, 2015; Kaden \& Kolbe, 2013) }\end{array}$ \\
\hline & & $\begin{array}{l}\text { Core and perimeter } \\
4 \text { perimeter and } 1 \text { core zone per floor }\end{array}$ & 3 & $\begin{array}{l}\text { (CARBSE, 2016; Chen et al., 2017; Heiple \& } \\
\text { Sailor, 2008) }\end{array}$ \\
\hline & & Detailed & 1 & (Caputo et al., 2013) \\
\hline
\end{tabular}




\begin{tabular}{|c|c|c|c|c|}
\hline Layer & Characteristic & Descriptor & Count & Examples \\
\hline & & Based on layouts and activities & & \\
\hline & & $\begin{array}{l}\text { Shoebox } \\
\text { As detailed in Dogan and Reinhardt (2017) }\end{array}$ & 1 & (Dogan \& Reinhart, 2017) \\
\hline & Fabric \& & Single archetype & 3 & $\begin{array}{l}\text { (Booth et al., 2012; Koene, Bakker, Lanceta, \& } \\
\text { Narmsara, 2014; Shimoda, Fujii, Morikawa, \& } \\
\text { Mizuno, 2004) }\end{array}$ \\
\hline & Systems & Multiple archetypes & 27 & $\begin{array}{l}\text { (Cerezo Davila, 2017; Chen et al., 2017; Gupta, } \\
\text { 2009) }\end{array}$ \\
\hline & & Stochastic selection & 2 & (Evans et al., 2017; Nägeli et al., 2018) \\
\hline \multirow{10}{*}{ 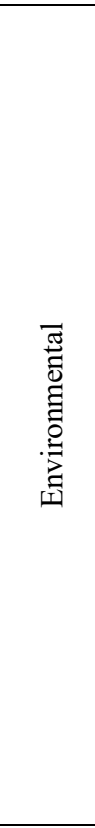 } & \multirow{4}{*}{$\begin{array}{l}\text { Surroundings } \\
\& \text { Orientation }\end{array}$} & $\begin{array}{l}\text { Volumetric } \\
\text { Buildings expressed as idealised volumes }\end{array}$ & 9 & $\begin{array}{l}\text { (CARBSE, 2016; Jones, Williams, \& Lannon, 2000; } \\
\text { Mhalas et al., 2013) }\end{array}$ \\
\hline & & $\begin{array}{l}\text { Standalone } \\
\text { Orientation considered }\end{array}$ & 13 & $\begin{array}{l}\text { (Caputo et al., 2013; Nägeli et al., 2018; Symonds et } \\
\text { al., 2016) }\end{array}$ \\
\hline & & $\begin{array}{l}\text { Contextual } \\
\text { Orientation and shading included }\end{array}$ & 7 & $\begin{array}{l}\text { (Cerezo Davila, 2017; Dogan \& Reinhart, 2017; } \\
\text { Evans et al., 2017) }\end{array}$ \\
\hline & & $\begin{array}{l}\text { Interactive } \\
\text { Orientation, shading and interactions with } \\
\text { surroundings }\end{array}$ & 2 & (Kaden \& Kolbe, 2013; Robinson et al., 2009) \\
\hline & \multirow{4}{*}{ Climate } & $\begin{array}{l}\text { None } \\
\text { No weather or climate variations }\end{array}$ & 2 & (Dall'O' et al., 2012; Jones et al., 2000) \\
\hline & & $\begin{array}{l}\text { Steady-state } \\
\text { Long range averages used }\end{array}$ & 8 & $\begin{array}{l}\text { (Gupta, 2009; Hughes, Palmer, \& Pope, 2013; } \\
\text { Mhalas et al., 2013) }\end{array}$ \\
\hline & & $\begin{array}{l}\text { Historic } \\
\text { Daily variability based on historic data }\end{array}$ & 19 & $\begin{array}{l}\text { (Caputo et al., 2013; Clarke et al., 2008; Symonds et } \\
\text { al., 2016) }\end{array}$ \\
\hline & & $\begin{array}{l}\text { Actual } \\
\text { Locally collected data used }\end{array}$ & 3 & $\begin{array}{l}\text { (Kaden \& Kolbe, 2013; Nouvel et al., 2013; } \\
\text { Robinson et al., 2009) }\end{array}$ \\
\hline & \multirow{2}{*}{ Municipal } & Not included & 30 & $\begin{array}{l}\text { (Cerezo Davila, 2017; Chen et al., 2017; Fonseca, } \\
\text { Nguyen, Schlueter, \& Marechal, 2016) }\end{array}$ \\
\hline & & $\begin{array}{l}\text { Included } \\
\text { e.g. for street lighting, water pumping }\end{array}$ & 2 & (Kaden \& Kolbe, 2013; Robinson et al., 2009) \\
\hline \multirow{11}{*}{ 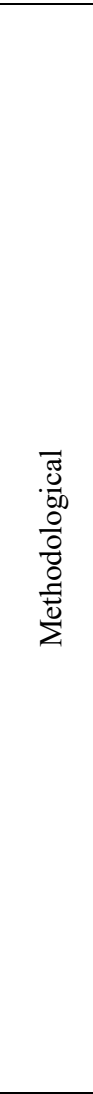 } & \multirow{3}{*}{$\begin{array}{l}\text { Stock } \\
\text { Dynamics }\end{array}$} & $\begin{array}{l}\text { Snapshot } \\
\text { Static stock evaluated at a single point }\end{array}$ & 32 & $\begin{array}{l}\text { (Caputo et al., 2013; Koene et al., 2014; Nouvel et } \\
\text { al., 2013) }\end{array}$ \\
\hline & & $\begin{array}{l}\text { Time series } \\
\text { Historic stock evolution data included }\end{array}$ & 0 & \\
\hline & & $\begin{array}{l}\text { Dynamic } \\
\text { Dynamic updates to reflect redevelopment }\end{array}$ & 0 & \\
\hline & \multirow{4}{*}{$\begin{array}{l}\text { Form of } \\
\text { Calculation }\end{array}$} & $\begin{array}{l}\text { Reduced order model } \\
\text { e.g. resistor-capacitor models or quasi- } \\
\text { steady-state }\end{array}$ & 17 & $\begin{array}{l}\text { (Koene et al., 2014; Mata et al., 2013; Nouvel et al., } \\
\text { 2013) }\end{array}$ \\
\hline & & $\begin{array}{l}\text { Scaled dynamic model } \\
\text { Dynamic simulation of a limited number of } \\
\text { archetype or sample buildings }\end{array}$ & 7 & $\begin{array}{l}\text { (Caputo et al., 2013; CARBSE, 2016; Dall'O' et al., } \\
\text { 2012) }\end{array}$ \\
\hline & & $\begin{array}{l}\text { Meta model } \\
\text { Regression/machine learning techniques to } \\
\text { generate surrogate models }\end{array}$ & 1 & (Symonds et al., 2016) \\
\hline & & $\begin{array}{l}\text { Dynamic simulation } \\
\text { Dynamic thermal simulation of whole } \\
\text { building stock }\end{array}$ & 7 & $\begin{array}{l}\text { (Cerezo Davila, 2017; Chen et al., 2017; Dogan \& } \\
\text { Reinhart, 2017) }\end{array}$ \\
\hline & \multirow{2}{*}{$\begin{array}{l}\text { Treatment of } \\
\text { Uncertainty }\end{array}$} & $\begin{array}{l}\text { Deterministic } \\
\text { Given set of inputs has a single set of } \\
\text { outputs }\end{array}$ & 28 & $\begin{array}{l}\text { (Caputo et al., 2013; Heiple \& Sailor, 2008; } \\
\text { Shimoda et al., 2004) }\end{array}$ \\
\hline & & $\begin{array}{l}\text { Probabilistic } \\
\text { Model output takes the form of a } \\
\text { distribution of possible values }\end{array}$ & 4 & $\begin{array}{l}\text { (Booth et al., 2012; Cerezo Davila et al., 2017; } \\
\text { Symonds et al., 2016) }\end{array}$ \\
\hline & \multirow{2}{*}{$\begin{array}{l}\text { Temporal } \\
\text { Resolution }\end{array}$} & Annual & 16 & $\begin{array}{l}\text { (Clarke et al., 2008; Filogamo et al., 2014; Nägeli et } \\
\text { al., 2018) }\end{array}$ \\
\hline & & Granular & 16 & $\begin{array}{l}\text { (Dogan \& Reinhart, 2017; Heiple \& Sailor, 2008; } \\
\text { Mata et al., 2013) }\end{array}$ \\
\hline
\end{tabular}


Figure 3 illustrates the diverse range of approaches which have been undertaken where the weight of the links between characteristics reflects the number of models which share those two characteristics. It is clear that models typically use simpler approaches for most characteristics with a few which are more complex. This targeted application of complexity has close parallels with the concept of "fit-for-purpose modelling" as described by Gaetani et al. (2016) in which the "the most appropriate model for a specific case is characterised by the lowest complexity, while preserving its validity with respect to the aim of the simulation." These trade-offs between simplicity and validity inherently relate to the underlying purpose for which the model was developed: for example, characterising long-wave radiative heat transfer between external surfaces is a low priority in London where surface temperatures are relatively low, but a dynamic simulation model which allows detailed simulation of retrofit option is important due to the long life-span of the existing building stock.

\section{Context-specific modelling challenges for Ahmedabad}

The application of a complex large-scale model to a new context inevitably brings a range of challenges, both in terms in terms of data and modelling. In creating a model of Ahmedabad, data collection is a key challenge - very limited data exists documenting occupant behaviour and patterns of use (Bardhan, Debnath, Jana, \& Norford, 2018; Debnath, Bardhan, \& Jain, 2017). This datascarcity extends to building fabric and systems and is exacerbated by the diversity of a building stock which has only relatively recently been subject to systematic building regulations and associated enforcement. (Nutkiewicz, Jain, \& Bardhan, 2018).

However, the modelling process itself presents additional challenges. As noted earlier, a model is not a neutral tool and the choice of which elements to simplify and which to develop in detail is driven by the demands of context and model purpose. Since Ahmedabad is an example of an under-represented context in the field of large-scale building stock energy models, there are a number of features of the context which have not been priorities for development for existing models:

- Thermal zoning - simplified zoning approaches need to take account of domestic cooling practices in the global south which often focus on cooling individual rooms (McNeil \& Letschert, 2008).

- Municipal services are a factor of interest for urban local bodies and there is considerable potential for energy savings (International Finance Corporation, Bureau of Energy Efficiency, Alliance to Save Energy, \& Alliance to Save Energy/South East Asia, 2008)

- Climate - Urban heat island implications are significant (Mathew, Chaudhary, Gupta, Khandelwal, \& Kaul, 2015)
- Surroundings and orientation - Long-wave radiative exchange between buildings is significant at lower latitudes. Ahmedabad is characterised as an extreme hot dry climate with particularly high surface temperatures where these effects are likely to be significant (Evins et al., 2014).

- Stock dynamics - New, potentially unplanned stock must be modelled as well as existing due to rate of new development (Manu et al., 2011).

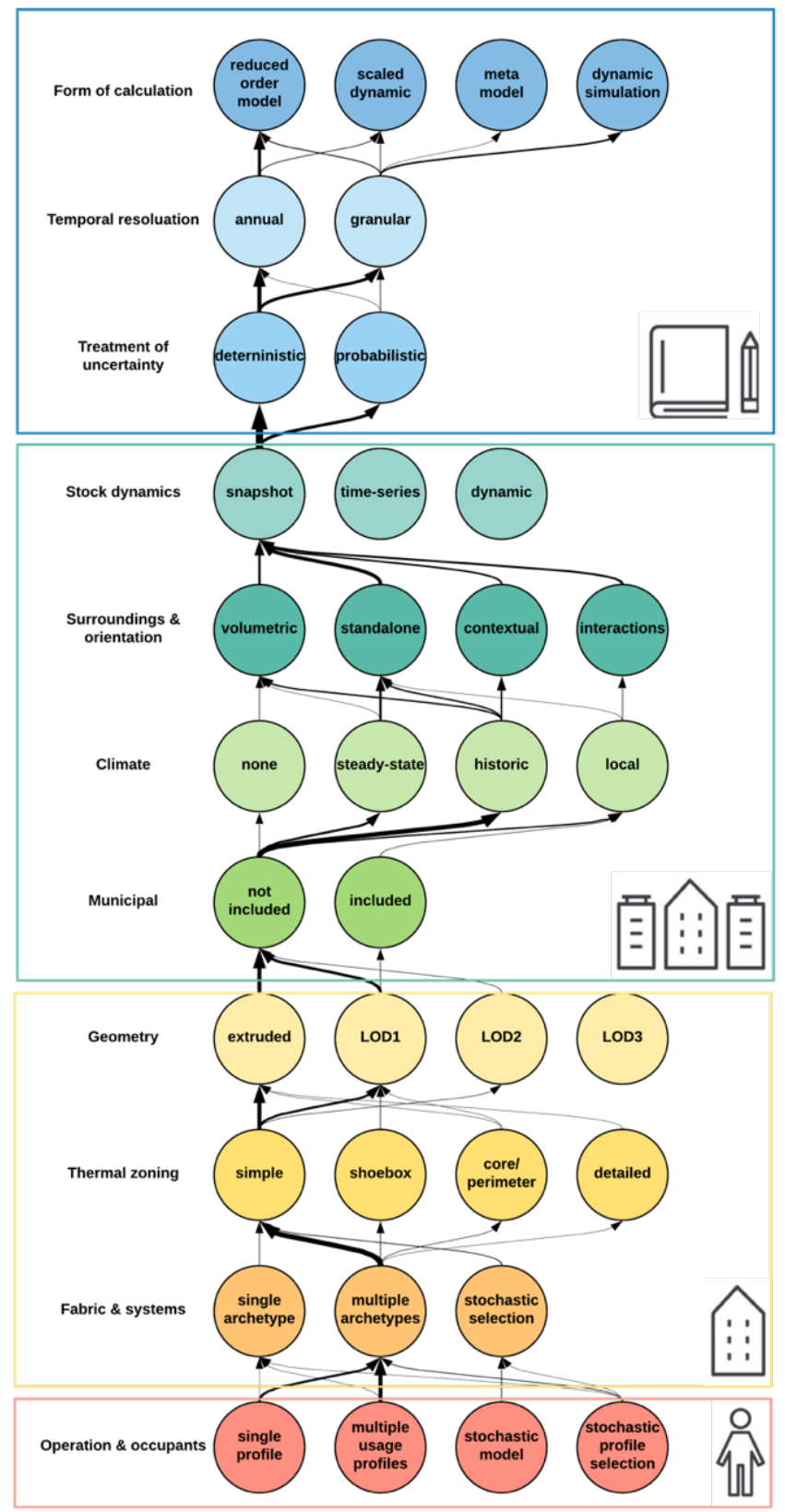

Figure 3: Model characteristics map

Figure 4 extends the analysis shown in Figure 3 by plotting the different approaches to each model characteristic according to their complexity and suitability for the context of Ahmedabad. The lower right quadrant of Figure 3 contains the optimal choice of an approach which is highly suitable for the context with low 
complexity. The upper right quadrant contains the next preferred options, those which are highly suitable, but which are complex, while the upper left quadrant contains the approaches which are least preferred, increasing the complexity of the model with limited gains in suitability.

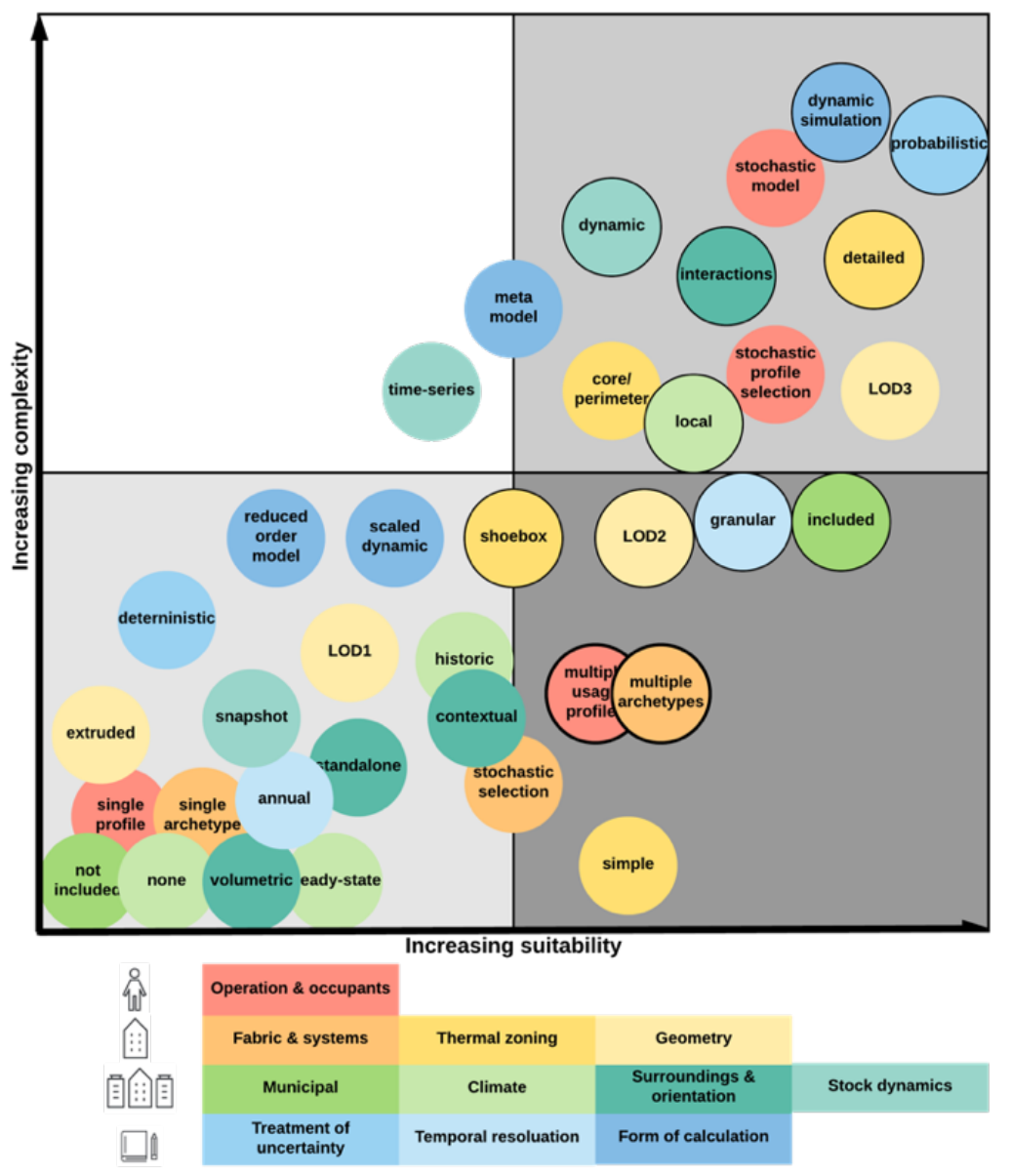

Figure 4: Trade-offs between complexity and suitability of different approaches to the 11 identified model characteristics

It should be noted that the complexity burden of the model may be cumulative, for example, combining a detailed zoning model and the interactions between buildings may be beyond the scope of the available computational resources, forcing a sub-optimal choice to be made for one of these elements.

Referring back to Figure 3, It is clear that this selection of modelling approaches represents a set of requirements not met by any existing large-scale building energy models. In particular, the need to accommodate local climate, interactions between buildings and a rapidly developing building stock will require significant development work. This is coupled with the data collection challenges associated with defining usage and building archetype.

\section{Conclusions and policy implications}

The importance of large-scale building energy models as a tool for supporting the deep decarbonisation of urban centres is increasing. However, such models have been overwhelmingly developed for cities in Europe and the USA and as a result lack features which will be essential to the valid simulation of energy demand in rapidly urbanising countries in the global south which are also faced with extreme climactic conditions.

A novel model classification scheme was developed to allow existing models to be explored in detail and create a framework for assessing their appropriateness for the case of the city of Ahmedabad, Gujarat. The framework addresses the multiple challenges of developing a largescale building energy model for a city in the global south and highlights the dangers of unquestioning replication of models developed for very different contexts. Mapping the simulation aims against the model characteristics allowed the key requirements for a new model to be identified and defined a programme of work necessary to develop modelling strategies to address the needs of the particular context.

While the classification framework developed in this study is applied to a particular context, the framework is applicable to any context and can provide a useful tool to assess the adequacy of existing models to capture its unique circumstances. A key outcome of this process is the ability to clearly identify additional development work which might be required to improve the representation in each case. 


\section{References}

Anderson, B. R., Chapman, P. F., Cutland, N. ., Dickson, C. M., Henderson, G., Henderson, J. H., ... Shorrock, L. D. (2002). BREDEM-12: model description, 2001 update (1st ed.). Watford: CRC, Construction Research Communications Ltd.

ASHRAE. (2013). Chapter 19 - Energy Estimating and Modelling Methods. In 2013 ASHRAE Handbook Fundamentals (SI Edition). ASHRAE.

ASHRAE. (2103). ANSI/ASHRAE Standard 169-2013 (p. 104). ASHRAE.

Bardhan, R., Debnath, R., Jana, A., \& Norford, L. K. (2018). Investigating the association of healthcareseeking behavior with the freshness of indoor spaces in low-income tenement housing in Mumbai. Habitat International, 71, 156-168.

Bhattacharyya, S. C., \& Timilsina, G. R. (2009). Energy Demand Models For Policy Formulation: A Comparative Study Of Energy Demand Models. The World Bank.

Booth, A. T., Choudhary, R., \& Spiegelhalter, D. J. (2012). Handling uncertainty in housing stock models. Building and Environment, 48, 35-47.

CARBSE. (2016). Impact of Building Energy Codes at the City Level: Energy Efficiency Interventions in Cities. CEPT University.

Cerezo Davila, C. (2017). Building Archetype Calibration for Effective Urban Building Energy Modeling. Massachusetts Institute of Technology, Cambridge, Massachusetts.

Cerezo Davila, C., Jones, N., Al-Mumin, A., Hajiah, A., \& Reinhart, C. (2017). Implementation of a calibrated Urban Building Energy Model (UBEM) for the evaluation of energy efficiency scenarios in a Kuwaiti residential neighborhood (p. 10). Presented at the Building Simulation 2017, San Francisco, USA.

Chen, Y., Hong, T., \& Piette, M. A. (2017). Automatic generation and simulation of urban building energy models based on city datasets for city-scale building retrofit analysis. Applied Energy, 205, 323-335.

dados, nour, \& connell, raewyn. (2012). the global south. Contexts, 11(1, taking on the issues), 12-13.

Davis, L. W., \& Gertler, P. J. (2017). Contribution of air conditioning adoption to future energy use under global warming. Proceedings of the National Academy of Sciences, 112(19), 5962-5967.

Debnath, R., Bardhan, R., \& Jain, R. K. (2017). A datadriven and simulation approach for understanding thermal performance of slum redevelopment in Mumbai, India, 8.

Dogan, T., \& Reinhart, C. (2017). Shoeboxer: An algorithm for abstracted rapid multi-zone urban building energy model generation and simulation. Energy and Buildings, 140, 140-153.
Evans, S., Liddiard, R., \& Steadman, P. (2017a). 3DStock: A new kind of three-dimensional model of the building stock of England and Wales, for use in energy analysis. Environment and Planning B: Urban Analytics and City Science, 44(2), 227-255.

Evins, R., Dorer, V., \& Carmeliet, J. (2014). Simulating external longwave radiation exchange for buildings. Energy and Buildings, 75, 472-482.

Fonseca, J. A., Nguyen, T.-A., Schlueter, A., \& Marechal, F. (2016). City Energy Analyst (CEA): Integrated framework for analysis and optimization of building energy systems in neighborhoods and city districts. Energy and Buildings, 113, 202-226.

Fonseca, J. A., \& Schlueter, A. (2015). Integrated model for characterization of spatiotemporal building energy consumption patterns in neighborhoods and city districts. Applied Energy, 142, 247-265.

Frayssinet, L., Merlier, L., Kuznik, F., Hubert, J.-L., Milliez, M., \& Roux, J.-J. (2018). Modeling the heating and cooling energy demand of urban buildings at city scale. Renewable and Sustainable Energy Reviews, 81, 2318-2327.

Gaetani, I., Hoes, P.-J., \& Hensen, J. L. M. (2016). Occupant behavior in building energy simulation: Towards a fit-for-purpose modeling strategy. Energy and Buildings, 121, 188-204.

Heiple, S., \& Sailor, D. J. (2008). Using building energy simulation and geospatial modeling techniques to determine high resolution building sector energy consumption profiles. Energy and Buildings, 40(8), 1426-1436.

Henderson, J., \& Hart, J. (2013). A technical description of the BRE Domestic Energy Model - 2012. Building Research Establishment.

Ignatius, M., Wong, N. H., \& Jusuf, S. K. (2016). The significance of using local predicted temperature for cooling load simulation in the tropics. Energy and Buildings, 118, 57-69.

International Energy Agency. (2015). India Energy Outlook (p. 191). Paris, France: IEA

International Finance Corporation, Bureau of Energy Efficiency, Alliance to Save Energy, \& Alliance to Save Energy/South East Asia. (2008). INDIA Manual for the Development of Municipal Energy Efficiency Projects (p. 130). New Delhi, India.

Kaden, R., \& Kolbe, T. H. (2013). CITY-WIDE TOTAL ENERGY DEMAND ESTIMATION OF BUILDINGS USING SEMANTIC 3D CITY MODELS AND STATISTICAL DATA. In ISPRS Annals of Photogrammetry, Remote Sensing and Spatial Information Sciences (Vol. II-2/W1, pp. 163171). Istanbul, Turkey.

Kokogiannakis, G., Strachan, P., \& Clarke, J. (2008). Comparison of the simplified methods of the ISO 13790 standard and detailed modelling programs in a 
regulatory context. Journal of Building Performance Simulation, 1(4), 209-219.

Manu, S., Wong, J., Rawal, R., Thomas, P. C., Kumar, S., \& Deshmukh, A. (2011). An initial parametric evaluation of the impact of the energy conservation building code of India on commercial building sector. In Proceedings of Building Simulation 2011 (pp. 1571-1578). Sydney.

Mathew, A., Chaudhary, R., Gupta, N., Khandelwal, S., \& Kaul, N. (2015). Study of Urban heat Island Effect on Ahmedabad City and Its Relationship with Urbanization and Vegetation Parameters. International Journal of Computer \& Mathematical Sciences, 4, 10.

McNeil, M. A., \& Letschert, V. E. (2008). Future Air Conditioning Energy Consumption in Developing Countries and what can be done about it: The Potential of Efficiency in the Residential Sector ( $\mathrm{p}$. 15). Berkley, California: Lawrence Berkeley National Laboratory.

Nägeli, C., Camarasa, C., Jakob, M., Catenazzi, G., \& Ostermeyer, Y. (2018). Synthetic Building Stocks as a Way to Assess the Energy Demand and Greenhouse Gas Emissions of National Building Stocks. Energy and Buildings.

Nouvel, R., Schulte, C., Eicker, U., Pietruschka, D., \& Coors, V. (2013). City GML - Based 3D city model for energy diagnostics and urban energy policy support. In Proceedings of BS2013 (pp. 218-225). Chambéry, France.

Nutkiewicz, A., Jain, R. K., \& Bardhan, R. (2018). Energy modeling of urban informal settlement redevelopment: Exploring design parameters for optimal thermal comfort in Dharavi, Mumbai, India. Applied Energy, 231, 433-445.

Raslan, R., \& Davies, M. (2010). Results variability in accredited building energy performance compliance demonstration software in the UK: an inter-model comparative study. Journal of Building Performance Simulation, 3(1), 63-85.

Robinson, D., Haldi, F., Kämpf, J., Leroux, P., Perez, D., Rasheed, A., \& Wilke, U. (2009). CITYSIM: COMPREHENSIVE MICRO-SIMULATION OF RESOURCE FLOWS FOR SUSTAINABLE URBAN PLANNING, 8.

Roy, J. (2000). The rebound effect: some empirical evidence from India. Energy Policy, 6.

Saltelli, A., Aleksankina, K., Becker, W., Fennell, P., Ferretti, F., Holst, N., ... Wu, Q. (2019). Why so many published sensitivity analyses are false: A systematic review of sensitivity analysis practices. Environmental Modelling \& Software.

Santamouris, M., Papanikolaou, N., Livada, I., Koronakis, I., Georgakis, C., Argiriou, A., \& Assimakopoulos, D. . (2001). On the impact of urban climate on the energy consumption of buildings. Solar Energy, 70(3), 201-216.

Shimoda, Y., Fujii, T., Morikawa, T., \& Mizuno, M. (2004). Residential end-use energy simulation at city scale. Building and Environment, 39(8), 959-967.

Shnapp, S., \& Laustsen, J. (2013). MITIGATION POTENTIAL FROM INDIA'S BUILDINGS. Global Buildings Performance Network.

Sokol, J., Cerezo Davila, C., \& Reinhart, C. F. (2017). Validation of a Bayesian-based method for defining residential archetypes in urban building energy models. Energy and Buildings, 134, 11-24.

Sousa, G., Jones, B. M., Mirzaei, P. A., \& Robinson, D. (2017). A review and critique of UK housing stock energy models, modelling approaches and data sources. Energy and Buildings, 151, 66-80.

Sunikka-Blank, M., Bardhan, R., \& Haque, A. N. (2019). Gender, domestic energy and design of inclusive lowincome habitats: A case of slum rehabilitation housing in Mumbai, India. Energy Research \& Social Science, $49,53-67$.

Swan, L. G., \& Ugursal, V. I. (2009). Modeling of enduse energy consumption in the residential sector: A review of modeling techniques. Renewable and Sustainable Energy Reviews, 13, 1819-1835.

Symonds, P., Taylor, J., Chalabi, Z., Mavrogianni, A., Davies, M., Hamilton, I., ... Macintyre, H. (2016). Development of an England-wide indoor overheating and air pollution model using artificial neural networks. Journal of Building Performance Simulation, 9(6), 606-619.

Tian, W., \& Choudhary, R. (2012). A probabilistic energy model for non-domestic building sectors applied to analysis of school buildings in greater London. Energy and Buildings, 54, 1-11.

United Nations, Department of Economic and Social Affairs, Population Division. (2018). World Urbaniztion Prospects: The 2018 revision, online edition. Retrieved from https://esa.un.org/unpd/wup/Country-Profiles/

Urban, F., Benders, R. M. J., \& Moll, H. C. (2007). Modelling energy systems for developing countries. Energy Policy, 35(6), 3473-3482.

Yamaguchi, Y., Suzuki, Y., Choudhary, R., Booth, A., \& Shimoda, Y. (2013). URBAN-SCALE ENERGY MODELING OF FOOD SUPERMARKET CONSIDERING UNCERTAINTY. In Proceedings of BS2013 (pp. 1382-1388). Chambéry, France.

\section{Acknowledgements}

Pamela Fennell and Paul Ruyssevelt's work on this paper was supported by the iNUMBER project, grant number EP/ R008620/1. Rajan Rawal and Veeren Poola's work on this paper was supported by the iNumber project DST/TMD/UKBEE/2017/18 (G) dated 29 ${ }^{\text {th }}$ Dec 2017. 